\title{
Spatial variability in soil pH and land use as the main influential factor in the red beds of the Nanxiong Basin, China
}

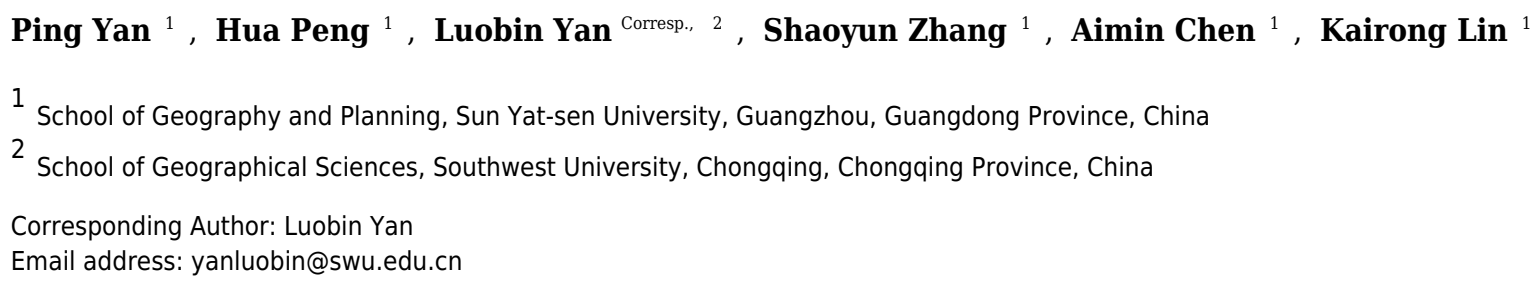

Soil $\mathrm{pH}$ is the main factor affecting soil nutrient availability and chemical substances in soil. It is of great significance to study the spatial variability of soil pH for the management of soil nutrients and the prediction of soil pollution. In order to explore the causes of spatial variability in soil pH in red-bed areas, the Nanxiong Basin in south China was selected as an example, and soil pH was measured in the topsoil by nested sampling (0-20 cm depth). The spatial variability characteristics of soil pH were analyzed by geostatistics and classical statistical methods, and the main factors influencing spatial variability in soil $\mathrm{pH}$ are discussed. The coefficient of variation in the red-bed areas of Nanxiong Basin was $17.18 \%$, indicating moderate variability. Geostatistical analysis showed that the spherical model is the optimal theoretical model for explaining variability in soil $\mathrm{pH}$, which is influenced by both structural and random factors. Analysis of the spatial distribution and pattern showed that soil pH is relatively high in the northeast and southwest, and is lower in the northwest. These results indicate that land use patterns and topographic factors are the main and secondary influencing factors, respectively. 
1 SPATIAL VARIABILITY IN SOIL PH AND LAND USE AS

2 THE MAIN INFLUENTIAL FACTOR IN THE RED BEDS

3 OF THE NANXIONG BASIN, CHINA

4 Ping Yan ${ }^{1}$, Hua Peng 1 , Luobin Yan $^{2}$, Shaoyun Zhang ${ }^{1}$, Aimin Chen ${ }^{1}$, Kairong Lin ${ }^{1}$

$5{ }^{1}$ School of Geography and Planning, Sun Yat-sen University, Guangzhou, China

$6 \quad{ }^{2}$ School of Geographical Sciences, Southwest University, Chongqing, China

7 Corresponding Author:

8 Luobin Yan $^{2}$

9 No.2 Tiansheng Road, Beibei district, Chongqing, 400715, P.R. China

10 Email address:

yanluobin@swu.edu.cn 
11 Spatial variability in soil $\mathrm{pH}$ and land use as the main

12 influential factor in the red beds of the Nanxiong

\section{Basin, China}

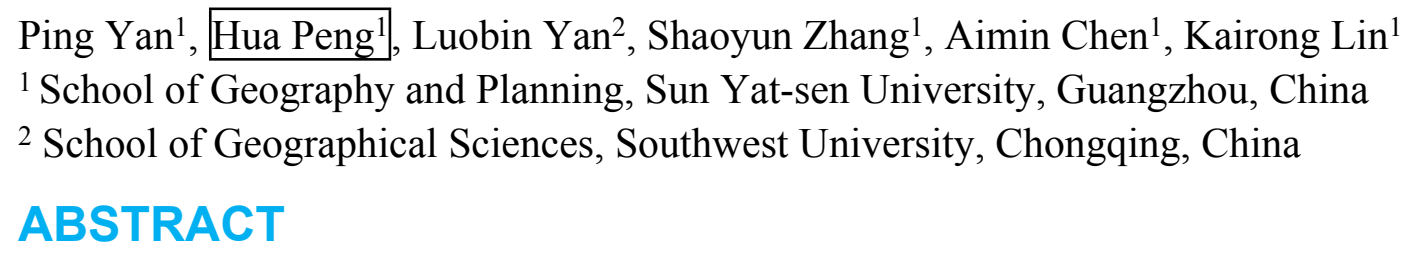

Soil $\mathrm{pH}$ is the main factor affecting soil nutrient availability and chemical substances in soil. It is of great significance to study the spatial variability of soil $\mathrm{pH}$ for the management of soil nutrients and the prediction of soil pollution. In order to explore the causes of spatial variability in soil $\mathrm{pH}$ in red-bed areas, the Nanxiong Basin in south China was selected as an example, and soil $\mathrm{pH}$ was measured in the topsoil by nested sampling $(0-20 \mathrm{~cm}$ depth). The spatial variability characteristics of soil $\mathrm{pH}$ were analyzed by geostatistics and classical statistical methods, and the main factors influencing spatial variability in soil $\mathrm{pH}$ are discussed. The coefficient of variation in the red-bed areas of Nanxiong Basin was $17.18 \%$, indicating moderate variability. Geostatistical analysis showed that the spherical model is the optimal theoretical model for explaining variability in soil $\mathrm{pH}$, which is influenced by both structural and random factors. Analysis of the spatial distribution and pattern showed that soil $\mathrm{pH}$ is relatively high in the northeast and southwest, and is lower in the northwest. These results indicate that land use patterns and topographic factors are the main and secondary influencing factors, respectively.

\section{INTRODUCTION}

Soil $\mathrm{pH}$ is an indicator of the acidity or alkalinity of soil, and is a reflection of important physical and chemical properties determining soil quality (Nagy \& Kónya, 2007). Soil pH also has a profound impact on a number of other soil properties. Extremes in acidity or alkalinity will change the nutrients available and result in the unbalanced absorption of elements in plants (Zhao et al., 2011).

Spatial heterogeneity refers to the lack of homogeneity and the complexity in the distribution in space of the properties of a system (Nagy \& Kónya, 2007). The spatial heterogeneity of soil parameters such as $\mathrm{pH}$ and content of organic matter and of nitrogen, phosphorus and potassium, has an important influence on the distribution and spatial pattern of plants (Stoyan et al., 2000; Augustine \& Frank, 2001; Silvia et al., 2016). Studying the spatial heterogeneity and the driving factors behind soil properties is significant for revealing ecosystem function and biodiversity (Augustine \& Frank, 2001).

With the continuous development of geographic information technology, studying the spatial variability of soil properties using a combination of geostatistics and GIS (Geographical 
Information System) technology has become one of the most important topics in the different fields in which soil is investigated (Romano, 1993; Foroughifar et al., 2013). In conventional soil survey soil properties are recorded at representative sites and assigned to entire mapping unit, which are delineated using both physio-graphic and geopedologic approaches (Shit, et al., 2016). Although soil surveyors are very well aware of the spatial variability of soil properties, conventionally prepared soil maps do not reflect it as soil units are limited by boundaries (Heuvelink \& Webster, 2001). In addition, the conventional method of soil analysis and interpretation are laborious, time consuming, hence becoming expensive. Starting near the end of the 1970s, scholars worldwide applied geostatistics to study the spatial variability of soil properties (Trangmar, Yost, \& Uehara, 1986).

Geostatistics is a widely used method for studying the spatial distribution of regionalized variables (Liu, Shao, \& Wang, 2012; Emadi et al., 2016; Mohamed et al., 2018). Many scholars have studied the spatial distribution characteristics of various soil properties by this method (Zhang \& Li, 2002; Zhang \& Li, 2010; Liu, Shao, \& Wang, 2011; Turgut \& Öztaş, 2012; Liu, Shao, \& Wang, 2013a). However, most of these studies were limited to a single terrain (Huang et al., 2012; Zhao et al., 2017), vegetation type (Riha, Senesac, \& Pallant, 1986; Zaremehrjardi, Taghizadehmehrjardi \& Akbarzadeh, 2010), land use (Mao et al., 2014; Miheretu \& Yimer, 2017) or other environmental factors, but analysis of them simultaneously is still lack.

Previous research has revealed that spatial variation in soil $\mathrm{pH}$ controls off-season $\mathrm{N}_{2} \mathrm{O}$ emission in agricultural soils (Russenes et al., 2016), however, soil properties vary in space and time across natural ecosystems (Bogunovic et al., 2017; Griffiths et al., 2017), and distributions of soil nutrients and related environmental factors depend on scale. Many studies have shown that soil $\mathrm{pH}$ is negatively correlated with many variables, such as soil organic carbon content, total nitrogen content, total phosphorus content, precipitation, temperature, and clay content ( $\mathrm{Liu}$, Shao, \& Wang, 2013b). Because the spatial distribution of soil $\mathrm{pH}$ has structural and stochastic characteristics, measuring it accurately has implications for crop production (Liu, Shao, \& Wang, 2013b). Reijonen, Metzler and Hartikainen (2016) demonstrated that soil pH dictates the accessibility of vanadium $\mathrm{V}(+\mathrm{V})$ and $\mathrm{V}(+\mathrm{IV})$, by investigating the chemical bioavailability of vanadium species. Therefore, it is important to study the spatial variability of soil $\mathrm{pH}$ on a regional scale together with the factors influencing it; these are important for the regulation of soil acidity and alkalinity, control of environmental pollution, and sustainable utilization and management of soil nutrients in addition to the ensemble of components of the regional ecological environment.

In China, the soil that forms on red beds is known as 'purple soil'(Yan et al., 2017). According to the results of the 34-province-wide soil census, the total area of purple soil is $2.17 \times 10^{5} \mathrm{~km}^{2}$ (Atsumoto et al., 2015). Many studies have shown that the purple soil formed on red-bed parent material is the most seriously eroded of all soil types in the Yangtze River Basin (Wang et al., 2009; Li et al., 2008). This is especially visible in humid regions, where severe erosion can threaten the sustainable development of agriculture in South China (Yan et al., 2017). The change in soil structure and the removal of topsoil resulting from erosion may cause the loss of nutrients and environmental degradation, thereby inhibiting plant growth (Sheoran, Sheoran, \& 
Poonia, 2010). The change in availability of soil nutrients affects not only crop production and vegetation growth, but also the structure of the ecological environment (Jin \& Jiang, 2002; Zhang et al., 2010). The factors affecting the spatial variability in soil $\mathrm{pH}$ in red-bed areas have not received much study. Therefore, studying the spatial distribution characteristics of soil $\mathrm{pH}$ is important for the sustainable utilization and management of soil nutrients and to improve soil productivity.

This study was carried out in a red-bed area in China with the following objectives: (i) to assess the value of the soil $\mathrm{pH}$; (ii) to reveal the spatial variability and the environmental influencing factors.

\section{MATERIALS AND METHODS}

\section{Study area}

Nanxiong Basin $\left(24^{\circ} 35^{\prime}-25^{\circ} 24^{\prime} \mathrm{N}, 113^{\circ} 50^{\prime}-114^{\circ} 44^{\prime} \mathrm{E}\right)$ is a narrow basin located in the northeast of Guangdong Province, China (Fig. 1). The elevation ranges from 48 to $1421 \mathrm{~m}$ above sea level (ASL). The subtropical monsoon climate here is characterised by long hot summers and short winters. The average temperature is $19.6^{\circ} \mathrm{C}$ and the annual precipitation and potential evaporation are $1555.1 \mathrm{~mm}$ and $1678.7 \mathrm{~mm}$, respectively (Yan et al., 2017). The total area of Nanxiong Basin is $3692 \mathrm{~km}^{2}$. The rainy season is from March to August. The dense river networks in Nanxiong Basin belong to the Pearl River systems. Purple soil accompanies the redbed parent material distributed in the central part of the basin. Nanxiong Basin is a red-bed basin with a severe soil erosion problem due to its dominant purple-soil texture (Calcaric Regosols in the FAO taxonomy); the red beds occupy an area of $1500 \mathrm{~km}^{2}$ and are mainly distributed in the central part of the basin. Land use mainly consists of farmland, shrubland, woodland, and grassland. The main vegetation communities are mixed forest of Pinus massoniana Lamb and broadleaf trees, secondary forest with mixed deciduous and broadleaf trees, and mainly artificial Eucalyptus and pine forests (Fig. 2, Yan et al., 2017). According to the 2009 1:5000 land-use map from the Shaoguan Municipal Bureau of Land and Resources, land-use types (Fig. 3) mainly include woodland in the Southeast part, farmland in stretched west to east in central part, bareland in the north and southwest part.

\section{Research method}

\section{Soil sample collection}

Samples were collected in November 2017 after crops (mainly rice) were fully harvested. A total of 225 samples were gathered from 0-20 cm depth by the nested sampling method at sampling densities. Soil samples were air-dried and passed through a $2 \mathrm{~mm}$ sieve for laboratory analysis of soil $\mathrm{pH}$ was measured in a 1:2.5 soil:water (DI water) suspension using a PP-50-P11 pH meter (with measurement error \pm 0.002 ) ( $\mathrm{Liu}$, Shao, \& Wang, 2013c) equipped with a calibrated combined glass electrode (Bogunovic et al., 2017). The global positioning system (GPS) (5-m 
123

124

125

126

127

128

129

130

131

132

133

134

135

136

137

138

139

140

141

142

143

144

145

146

147

148

149

150

151

precision) was then used to identify the site's longitude, latitude and elevation. The actual sampling sites were chosen to represent the main topography, land use, and vegetation types within the range of vision. Site slope and aspect measured with a geological compass, and information on human activities (irrigation, fertilizer use and crop yield) was collected from surveys of the local inhabitants. The distribution of sample points is shown in Figure 1.

\section{Data analysis}

Some basic statistics were calculated, such as the minimum, maximum, and mean values of measurements and their coefficient of variation (CV). The Kolmogorov-Smirnov (K-S) test and correlation analysis of soil $\mathrm{pH}$ with topographical variables were performed to analyse data distribution, using the statistical software SPSS 19 (IBM SPSS Statistics for Windows, IBM Corp., Armonk, NY, USA). GS+7 (Gamma Design Software, Plainwell, MI, USA) was used to do the geostatistical analysis. The K-S method was used to evaluate data normality and asymmetry in terms of skewness and kurtosis because these factors have important implications for the performance of the interpolation methods.

A semivariogram is the basic tool of geostatistics (Oliver \& Webster, 1986; Goovaerts, 1999; Nasseh et al., 2016). The formula used to calculate the semivariogram is:

$$
\gamma(h)=\frac{1}{2 N(h)} \sum_{i=1}^{N(h)}\left[Z\left(x_{i}\right)-Z\left(x_{i}+h\right)\right]^{2}
$$

In eqn. (1), $\mathrm{N}(\mathrm{h})$ is the logarithm of the distance when the distance equals $h$, and $Z\left(x_{i}\right)$ is the value at location $x_{i} ; Z\left(x_{i}+h\right)$ is the value at a distance $h$ from $x_{i}$ (Yang et al., 2016; Rosemary et al., 2017). Appropriate model functions were fitted to the semivariograms. The semivariograms were used to determine the degree of spatial variability on the basis of the classes of spatial dependence distinguished by Cambardella (1994), strong spatial dependence $\left(C_{0} /\left(C_{0}+C\right)>\right.$ $75 \%)$, moderate spatial dependence $\left(25 \%<C_{0} /\left(C_{0}+C\right)<75 \%\right)$ and weak spatial dependence $\left(C_{0} /\left(C_{0}+C\right)<25 \%\right)$. In ArcGIS 9.2 (ESRI 2006. ArcGIS Desktop: Redlands, CA:

Environmental Systems Research Institute.), we used kriging interpolation in the geostatistics module to draw the spatial distribution map of soil $\mathrm{pH}$ and the trend analysis chart in order to analyse the characteristics of the spatial variability. The main factors controlling spatial variation in soil $\mathrm{pH}$ and their influence were analysed using maps of the soil type, slope, aspect, elevation, and land use.

\section{RESULTS}

\section{Descriptive statistics of soil pH}

Descriptive statistics of soil $\mathrm{pH}$ is presented in Table 1. Soil $\mathrm{pH}$ of the study area ranged between 7.50 and 8.50 , with an average value of 8.04 and a median of 8.05 . The mean soil $\mathrm{pH}$ for the redbed region, which was calculated from 225 soil samples, is higher than the estimated mean soil $\mathrm{pH}$ for the whole of China (6.8) and lower than the mean soil $\mathrm{pH}$ for the Loess Plateau region (8.49). The main factors determining soil $\mathrm{pH}$ were the region's humid climate and the relatively 
159 high calcium carbonate content in the soft rock underlying the red beds. The criteria proposed by 160 Wilding (1985) were used to classify the parameters into most (CV > 35\%), moderate (CV 15$16135 \%)$ and least $(\mathrm{CV}<15 \%)$ variable classes. The standard deviation in soil $\mathrm{pH}$ values was 1.38 162 and the $\mathrm{CV}$ value for the $\mathrm{pH}$ in this area was $17.18 \%$. Accordingly, the $\mathrm{pH}$ in this area could be 163 classified as moderately variable. In general, $\mathrm{pH}$ is considered to be a stable soil parameter. Similar CV values were reported by Tsui, Chen, and Hsieh (2004), Fu, Tunney, and Zhang (2010), and Liu, Shao, and Wang (2013c), in all these studies, variability was found to be moderate. According to the observed trend in the accumulation frequency of soil pH (Fig. 4), the $\mathrm{pH}$ value in the study area was mainly in the range of 7.95-8.20. The K-S test showed that the $\mathrm{pH}$ values of the sample points were normally distributed, and thus meet the requirements of geostatistics analysis (Table 1).

\section{Spatial variability in soil pH}

\section{Isotropic semivariogram of soil $\mathrm{pH}$}

GS+7.0 software was used to fit the soil $\mathrm{pH}$ in the study area to the theoretical model (Table 2). The variogram's fitting model was selected based on the nugget effect, the coefficient of determination $\left(\mathrm{R}^{2}\right)$ and the range of variation (Bogunovic et al., 2017). As can be seen from Table 2, the value for nugget $\left(\mathrm{C}_{0}\right)$ is 0.12 , the value for sill $\left(\mathrm{C}_{0}+\mathrm{C}\right)$ is 0.18 , the ratio of nugget $\left(\mathrm{C}_{0}\right)$ and sill $\left(\mathrm{C}_{0}+\mathrm{C}\right)$ is $66.67 \%$, and the determination coefficient $\left(\mathrm{R}^{2}\right)$ is 0.812 . High coefficients of determination indicate that the models fitted the semivariogram well (Jeloudar et al., 2014). The nugget-sill ratio of $66.67 \%$, indicating that the soil $\mathrm{pH}$ had a moderate spatial dependence (Cambardella, 1994). The spherical model gave the best fit for the variation in soil $\mathrm{pH}$ in the study area. The main structural factors were climate, parent material and terrain; these can enhance the spatial dependency of soil $\mathrm{pH}$. In contrast, random factors, which are the result of human activity such as farming and fertilization, can make the spatial dependency of soil $\mathrm{pH}$ weaker (Isaaks \& Srivastava, 1989). This moderate spatial dependence of soil $\mathrm{pH}$ in the red beds implies that the spatial variation of soil $\mathrm{pH}$ in the study area is mainly caused by both structural and random factors.

As can be seen in Figure 5, when the separation distance is more than $161 \mathrm{~m}$, the semivariance fluctuates only slightly, and then stabilizes. This trend might be caused by differences in directional variation. The variance at $250 \mathrm{~m}$ implies that the range of the spatial dependence is much wider than the sampling interval. Therefore, the current sampling design was appropriate for this study.

In order to understand the characteristics of the spatial variation in soil $\mathrm{pH}$, the semivariogram was drawn in four directions, E-W $\left(0^{\circ}\right), \mathrm{NE}-\mathrm{SW}\left(45^{\circ}\right), \mathrm{S}-\mathrm{N}\left(90^{\circ}\right)$ and SE-NW $\left(135^{\circ}\right)$, using the GS+7.0 software. As shown in Figure 6, the spatial variation exhibits large differences in different directions, showing the heterogeneity. Table 3 shows that the best-fitting models in the four directions are all spherical. The nugget $\left(C_{0}\right)$ and sill $\left(C_{0}+C\right)$ values are different and their ratio ranges from $60.24 \%$ to $69.23 \%$, indicating moderate variation.

As shown in Figure 6, the range of the soil $\mathrm{pH}$ values from the northeast to the southwest $\left(45^{\circ}\right)$ and from the southeast to the northwest $\left(135^{\circ}\right)$ is significantly smaller than that from east to west 
$199\left(0^{\circ}\right)$ and from north to south $\left(90^{\circ}\right)$, indicating that the variation in the $0^{\circ}$ and $90^{\circ}$ directions is

200

201

202

203

204

205

206

207

208

209

210

211

212

more complex than those at $45^{\circ}$ and $135^{\circ}$.

From east to west $\left(0^{\circ}\right)$, when the separation distance is greater than $161 \mathrm{~m}$, the difference in the semivariance of the soil $\mathrm{pH}$ begins to fluctuate, first increasing and afterward decreasing to around 0.0388 . The semivariance from north to south $\left(90^{\circ}\right)$ shows the same trend, alternating between high and low, but the degree of fluctuation in the $\mathrm{E}-\mathrm{W}\left(0^{\circ}\right)$ direction is smaller. When the separation distance is larger than $169 \mathrm{~m}$, the variation of the soil $\mathrm{pH}$ in the NE-SW $\left(45^{\circ}\right)$ and SE-NW $\left(135^{\circ}\right)$ directions is more stable near 0.0388 , and the degree of variation is not very different. The main reason is that the area is near the badlands hills in the NE-SW and the SENW directions; the topography and parent materials are of great influence, and in the SE-NW direction there are more hills and larger undulations. However, in the $\mathrm{N}-\mathrm{S}$ and $\mathrm{E}-\mathrm{W}$ directions $\left(0^{\circ}\right.$ and $90^{\circ}$, respectively), the soil $\mathrm{pH}$ shows high spatial homogeneity because the relief is low and the only land use is farmland in these directions. Taken together, the soil $\mathrm{pH}$ in this study area has an obvious spatial heterogeneity, which is suitable for further interpolation analysis.

\section{Analysis of the spatial distribution of soil $\mathrm{pH}$}

The effect of trends is a prerequisite for and the basis of prediction by kriging interpolation. The number of parameters that are required for kriging interpolation becomes smaller as the order of the trend effect decreases. Thus, a lower order of the trend effect can reduce error, and many scholars take the lower-order trend among two trends as the trend to be used in conducting prediction by interpolation ( $\mathrm{Li}$ et al., 2013). Trend analysis can provide a study area sampling point and a three-dimensional perspective with information for the attribute value on the z-axis. The global trend in sampling data can be analysed from different perspectives.

As shown in Fig. 7, soil pH decreases from northeast to southwest, which is consistent with the result of semivariogram analysis. The soil $\mathrm{pH}$ values are higher in the northeast and southwest; this pattern can be explained by the difference in land use. In the northeastern and southwestern parts, the land is unused land with a high relief. Arable land is mainly distributed in the northwest, where the relief is low and the land is strongly affected by human activities such as the use of nitrogen fertilizer, which might cause a reduction of the $\mathrm{pH}$ value in soil (Yüksek et al., 2009).

Table 4 shows that the $\mathrm{pH}$ value of the $0-20 \mathrm{~cm}$ soil layer tends to decrease from upper slope to middle slope to downslope for slope below $20^{\circ}$, when slope over $20^{\circ}$, this trend is reversed (P $<0.05)$.

\section{Spatial distribution pattern of soil $\mathrm{pH}$}

Based on the semivariance function model and the spatial distribution trend analyses, the spatial distribution pattern of soil $\mathrm{pH}$ in the study area was analysed by interpolation analysis of the 3D map constructed with the GS+7.0 software (Nasseh et al., 2016). Kriging analysis of the 3D map shows that the soil $\mathrm{pH}$ varies greatly in the horizontal direction in the study area (Fig. 8); the soil $\mathrm{pH}$ is higher in the northeast and the southwest, increases towards the southwest, and decreases towards the northwest. The result of inverse distance weighting interpolation of the 3D map shows that the overall trend for the $\mathrm{pH}$ in the study area is consistent with the results from kriging interpolation (Fig. 9). 


\section{Analysis of influential factors}

242

Human activities and the natural environment always interact with each other. Natural factors such as climate, topography and soil properties greatly affect the way land is used by human beings and the method (Morales et al., 2009; Wang, Zhang \& Huang, 2009; Zucco et al., 2014). In turn, the human choice for different land uses will also affect natural factors such as vegetation types and the physical, chemical and biological properties of the soil.

A large number of studies have shown that the spatial variability of soil $\mathrm{pH}$ is related to many factors (Riha, Senesac \& Pallant, 1986; Kuzel et al., 1994; Russenes et al., 2016). In this study, the $\mathrm{CV}$ is $17.18 \%$, which can be classified as moderate variation, and is the result of both structural factors (parent material, topography, climate) and random factors (soil biology, human disturbance, sampling design and measurement error).

Although the spatial variation of soil $\mathrm{pH}$ in the study area is determined by structural factors such as topographic factors and the random factors of human fertilization, it is still not known to what extent each factor affects the spatial variation of soil $\mathrm{pH}$. Therefore, two factors (topographic factors and land use) will be further discussed here to demonstrate their influence.

\section{Topographic factors}

\section{Influence of slope and position along the slope on the spatial distribution of soil pH} Severe soil erosion can cause a decrease in the $\mathrm{pH}$ value (Schindelbeck et al., 2008). Due to the humid monsoon climate and the high erodibility of purple soil, which is caused by its high content of sandy particles, its $\mathrm{pH}$ value is generally lower than in the weathering sediments of red beds, which have a $\mathrm{pH}$ value higher than 8 .

In general, soil $\mathrm{pH}$ varies significantly between different slopes and positions along the slope (Henkel, 2003). Thus, the $\mathrm{pH}$ of surface soil $(0-20 \mathrm{~cm})$ also varies with slope and position, reflecting the geomorphic process.

Soil properties on different slope positions were significantly affected by the degree of soil development and the leaching processes (Tsui, Chen, and Hsieh, 2004). The effects of topographic factors on soil $\mathrm{pH}$ were discussed in this study. For slopes under $20^{\circ}$ in this study, the $\mathrm{pH}$ of soil is the highest on the downslope, followed by that in the middle slope, and is the lowest on the upper slope. In case of ploughed vineyard decrease of $\mathrm{pH}$ value along the slope catena was noticed by Kenderessy (2014), which indicates that calcic carbonates could be leached from the surface layer by excess water from upper positions as a result of accelerated erosion. For slopes over $20^{\circ}$, soils on the footslope which is a concave position has a significantly higher $\mathrm{pH}$ than those on other slope positions, similar results were reported by Tsui, Chen, \& Hsieh (2004) and Huggett (1975), who confirmed that slope, which is involved in the transport and accumulation of solutes, resulted in a higher $\mathrm{pH}$. Thus, to some extent factors affecting soil erosion have an influence on soil $\mathrm{pH}$. However, in this study case in red beds area the concrete mechanisms, how topographical factors affect the $\mathrm{pH}$ in different positions, needs 
278

279

280

281

282

283

284

285

286

287

288

289

290

291

292

293

294

295

296

297

298

299

300

301

302

303

304

305

306

307

308

309

310

311

312

313

314

315

316

317

further research.

In addition, as we know, topography is a structure factor influencing the spatial variability of soil $\mathrm{pH}$. In our study area, in the $\mathrm{E}-\mathrm{W}$ and $\mathrm{N}-\mathrm{S}$ directions $\left(0^{\circ}\right.$ and $90^{\circ}$, respectively), the soil $\mathrm{pH}$ shows high spatial homogeneity because the relief is low and the only land use is farmland. An important result is that the topography influences soil $\mathrm{pH}$ mainly through the slope and indirectly via effects on land use patterns; this is a general conclusion that has rarely been acknowledged elsewhere.

\section{Influence of aspect on the spatial distribution of soil $\mathrm{pH}$}

Different slope aspects experience different solar radiation, temperature and water conditions. The vegetation coverage is also different. Therefore, differences in physical, chemical, and biological processes in the topsoil are correlated with different aspect directions, leading to a heterogeneity in $\mathrm{pH}$ content and distribution in the topsoil (Vieira et al., 2009; Salehi, Esfandiarpour, \& Sarshogh, 2011). By combining the aspect distribution map of the study area and the geostatistical analysis module in the ArcGIS software, the spatial distribution map of the soil $\mathrm{pH}$ was analysed (Figs 10 and 11). The result shows that the average $\mathrm{pH}$ value varies with aspect of the slope in the study area. The soil $\mathrm{pH}$ values on north- and southwest-facing slopes are relatively higher than on slopes of other aspects.

The location of the study area, in the humid red-bed area in south China, is representative for the concentrated distribution of soft rock in red beds. The best fitting models were all spherical, with a high degree of fit for the spatial variability of soil $\mathrm{pH}$, and they were verified in various studies (Wang et al., 2011; Liu, Shao, \& Wang, 2013c), indicating that the spatial structure of soil $\mathrm{pH}$ in the study area was distinct.

Kerry and Oliver (2004) indicated that, as a rough guide, in future sampling intervals should be chosen to be less than half the variogram range. According to the results of this study, future sampling intervals for monitoring $\mathrm{pH}$ should be $80-100 \mathrm{~m}$.

\section{Land use pattern}

Different systems of land use result in different levels of human land-use activities and have different effects on soil properties. The results showed that land use had a significant effect on surface soil $\mathrm{pH}(P<0.05)$. As shown in Fig. 12, among the four categories of land use patterns (farmland, woodland, grassland and bare land), the average soil $\mathrm{pH}$ differs significantly between different land uses $(P<0.05)$. Among them, there is not much difference between woodland and grassland, though. The soil $\mathrm{pH}$ between different land use patterns varied from 8.09 for farmland to 7.98 for bare land, 7.97 for grassland and 7.96 for woodland. A comparison of the $\mathrm{pH}$ values in farmland and woodland topsoils shows that the $\mathrm{pH}$ value of woodland is lowest. An explanation for this might be that the tree species on woodland is Masson pine (Pinus massoniana Lamb), which has an acidifying effect on soil.

At $14.21 \%$, the $\mathrm{CV}$ of $\mathrm{pH}$ is lowest on bare land; the $\mathrm{pH}$ of grassland and woodland is lower than that of farmland (Table 5). However, previous research established that the $\mathrm{pH}$ of woodland and farmland had the lowest $\mathrm{CV}$, which could be the result of the uniform conditions in the region, such as small changes in slope and its direction, leading to a uniformity of soil 
318 (Cambardella, 1994; Kavianpoor et al., 2012; Jeloudar et al., 2014). The possible reasons 319 require further investigation.

320 On the whole, the spatial distribution of soil $\mathrm{pH}$ is closely related to land use (Mao et al., 321 2014). This might be caused by the application of urea fertilizer, which has been proven to increase the soil pH (Petrie \& Jackson, 1984).

Numerous studies have shown a decreasing soil $\mathrm{pH}$ with increasing number of cropping years (Meng, Li, \& Liu, 2000; Zhao, Wu, \& Liu, 2000). The average soil pH is the highest in farmland, followed by grassland and bare land, and the average $\mathrm{pH}$ in woodland is lowest. By studying the spatial variability of soil properties in an Alfisol soil catena, Rosemary et al. (2017) arrived at similar conclusions, namely that soil $\mathrm{pH}$ in paddies is high.

\section{Influence of aspect on the spatial distribution of soil $\mathrm{pH}$ needs a further research.}

\section{CONCLUSION}

330

331

332

333

334

335

336

337

338

339

340

341

342

343

344

345

346

347

348

349

350

351

352

353

The investigated parameters follow a normal distribution. For $\mathrm{pH}$, the best-fitting variogram model was a spherical one. A practical application of our research results may be that the cost of the production cycle can be reduced by the inclusion of the models we established for application in directional semivariograms in interpolation analysis, improving the reliability of local assessments of the analysed soil $\mathrm{pH}$. In order to reduce production costs, a sampling interval of $80-100 \mathrm{~m}$ is recommended for soil $\mathrm{pH}$. The spatial distribution maps based on the kriging interpolation method were successfully applied in soil $\mathrm{pH}$ studies.

In this study, the $\mathrm{CV}$ is $17.18 \%$, which can be classified as moderate variation, and is the result of both structural factors (parent material, topography, climate) and random factors (soil biology, human disturbance, sampling design and measurement error). This study focused on the spatial variability of soil $\mathrm{pH}$ as a result of the interaction of topographic factors, soil and land use patterns. In general, studying the spatial variability of soil $\mathrm{pH}$ can provide a theoretical basis for the restoration and improvement of soil quality, including the rapid restoration of soil in red-bed ecosystems and ecological reconstruction in the moist environment of south China.

\section{REFERENCES}

Atsumoto SM, Ishimatsu H, Shimada H, Sasaoka T, Matsui K, Jalu Kusuma G. 2015. Prevention of Acid Mine Drainage (AMD) by Using Sulfur-Bearing Rocks for a Cover Layer in a Dry Cover System in View of the Form of Sulfur. Inzynieria Mineralna 2: 29-35

Augustine DJ, Frank DA. 2001. Effects of migratory grazers on spatial heterogeneity of soil nitrogen properties in a grassland ecosystem. Ecology 82(11): 3149-3162 DOI $10.2307 / 2679841$.

Bogunovic I, Kisic I, Mesic M, Percin A, Zgorelec Z, Bilandžija D, Jonjica A, Pereirab P. 2017. Reducing sampling intensity in order to investigate spatial variability of soil ph, 
organic matter and available phosphorus using co-kriging techniques. a case study of acid soils in eastern croatia. Archiv für Acker- und Pflanzenbau und Bodenkunde 63(13): 18521863 Doi 10.1080/03650340.2017.1311013.

Bogunovic I, Trevisani S, Seput M, Juzbasic D, Durdevic B. 2017. Short-range and regional spatial variability of soil chemical properties in an agro-ecosystem in eastern croatia. Catena 154: 50-62 DOI 10.1016/j.catena.2017.02.018.

Cambardella CA, Moorman TB, Parkin TB, Karlen DL, Novak JM, Turco R, Konopka AE. 1994. Field-scale variability of soil properties in central iowa soils. Soilence Society of America Journal 58: 1501-1511 DOI 10.2136/sssaj1994.03615995005800050033x.

Emadi M, Shahriari AR, Sadegh-Zadeh F, Seh-Bardan BJ, Dindarlou A. 2016. Geostatistics-based spatial distribution of soil moisture and temperature regime classes in mazandaran province, northern iran. Archives of Agronomy \& Soil Science 62(4): 502-522 DOI 10.1080/03650340.2015.1065607.

Foroughifar H, Jafarzadeh AA, Torabi H, Pakpour A, Miransari M. 2013. Using geostatistics and geographic information system techniques to characterize spatial variability of soil properties, including micronutrients. Communications in Soil Science \& Plant Analysis 44(8): 1273-1281 DOI 10.1080/00103624.2012.758279.

Fu WJ, Tunney H, Zhang CS. 2010. Spatial variation of soil nutrients in a dairy farm and its implications for site-specific fertilizer application. Soil \& Tillage Research 106(2): 185-193 DOI 10.1016/j.still.2009.12.0.

Goovaerts P. 1999. Geostatistics in soil science: state-of-the-art and perspectives. Geoderma 89(1-2): 1-45 DOI 10.1016/S0016-7061(98)00078-0.

Griffiths NA, Hanson PJ, Ricciuto DM, Iversen CM, Jensen AM, Malhotra A, McFarlane KJ, NorbyRJ, Sargsyan K, Sebestyen SD, Shi XY,Walker AP, Eric JW, Warren JM, Weston DJ. 2017. Temporal and spatial variation in peatland carbon cycling and implications for interpreting responses of an ecosystem-scale warming experiment. Soil Science Society of America Journal 81(6): 1668-1688 DOI 10.2136/sssaj2016.12.0422.

Henkel TW. 2003. Monodominance in the ectomycorrhizal dicymbe corymbosa (caesalpiniaceae) from guyana. Journal of Tropical Ecology 19(4): 417-437 DOI 10.1017/S0266467403003468.

Heuvelink GBM, Webster R. 2001. Modeling soil variation: past, present, and future. Geoderma 100(3-4): 269-301 DOI 10.1016/S0016-7061(01)00025-8.

Huang Y, Chen L, Fu B, Huang Z, Gong J, Lu X. 2012. Effect of land use and topography on spatial variability of soil moisture in a gully catchment of the loess plateau, china. Ecohydrology 5(6): 826-833 DOI 10.1002/eco.273.

Huggett RJ. 1975. Soil landscape systems: a model of soil genesis. Geoderma 13(1), 1-22 DOI 10.1016/0016-7061(75)90035-X.

Isaaks EH, Srivastava RM. 1989. An introduction to applied geostatistics. New York: Oxford University Press.

Jeloudar ZJ, Shabaanzadeh S, Kavian A, Shokri M. 2014. Spatial Variability of Soil Features Affected by Landuse Type using Geostatistics. Ecopersia 2: 667-679 http://journals- 
old.modares.ac.ir/article_12810.html.

Jin J, Jiang C. 2002. Spatial variability of soil nutrients and site-specific nutrient management in the p.r. china. Computers \& Electronics in Agriculture 36(2-3): 165-172 DOI 10.1016/S0168-1699(02)00099-6.

Kavianpoor H, Ouri AE, Jeloudar ZJ, Kavian A. 2012. Spatial variability of some chemical and physical soil properties in nesho mountainous rangelands. American Journal of Environmental Engineering 2: 34-44 DOI 10.5923/j.ajee.20120201.06.

Kenderessy P, Lieskovsky J. 2014. Impact of the soil erosion on soil properties along a slope catena-case study horný ohaj vineyards, slovakia. Carpathian Journal of Earth \& Environmental Sciences 9(2): 143-152 https://www.researchgate.net/publication/286074060.

Kerry R, Oliver MA. 2004. Average variograms to guide soil sampling. International Journal of Applied Earth Observation \& Geoinformation 5: 307-325 DOI 10.1016/j.jag.2004.07.005.

Kuzel S, Nýdl V, Kolár L, Tichý R. 1994. Spatial variability of cadmium, ph, organic matter in soil and its dependence on sampling scales. Water Air \& Soil Pollution 78(1-2): 51-59. DOI $10.1007 / \mathrm{BF} 00475667$.

Li WH, Wang C, Yang M, Wang L. 2013. Trend effect and an isotropy of soil particle composition in the chengdu plain. Journal of Agricultural Science 5(2): 56-63 DOI 10.5539/jas.v5n2p56.

Li YC, Liu CX, Zhao CY, Huang JH. 2008. Spatiotemporal features of soil and water loss in the Three Gorges Reservoir Area of Chongqing. Journal of Geographical Sciences $\mathbf{6 3}$ (5):502-513 DOI 10.11821/xb200805006.

Liu ZP, Shao MA, Wang, YQ. 2011. Effect of environmental factors on regional soil organic carbon stocks across the loess plateau region, china. Agriculture Ecosystems \& Environment 142(3): 184-194 DOI 10.1016/j.agee.2011.05.002.

Liu ZP, Shao MA, Wang, YQ. 2012. Large-scale spatial variability and distribution of soil organic carbon across the entire loess plateau, china. Soil Research 50: 114-124 DOI 10.1071/SR11183.

Liu ZP, Shao MA, Wang, YQ. 2013a. Spatial patterns of soil total nitrogen and soil total phosphorus across the entire loess plateau region of china. Geoderma 197-198: 67-78 DOI 10.1071/SR12190.

Liu ZP, Shao MA, Wang, YQ. 2013b. Scale-dependent correlations between soil properties and environmental factors across the loess plateau of china. Soil Research 51(2): 112-123 DOI 10.1071/SR12190.

Liu ZP, Shao MA, Wang, YQ. 2013c. Large-scale spatial interpolation of soil pH across the Loess Plateau, China. Environmental Earth Sciences 69(8): 2731-2741 DOI 0.1007/s12665012-2095-z.

Mao Y, Sang S, Liu S, Jia J. 2014. Spatial distribution of ph and organic matter in urban soils and its implications on site-specific land uses in xuzhou, china. Comptes Rendus Biologies 337(5): 332-337 DOI /10.1016/j.crvi.2014.02.008.

Meng HG, Li Z, Liu YJ. 2000. Characteristics of the physical and chemical properties in the protected vegetable soils. Bulletin of Chinese Soil Science 31: 70-82. 
Miheretu B A, Yimer AA. 2017. Spatial variability of selected soil properties in relation to land use and slope position in gelana sub-watershed, northern highlands of ethiopia. Physical Geography 3: 1-16 DOI 10.1080/02723646.2017.13809.

Mohamed JEH, Abdelkader L, Mohamed F, Mohamed S. 2018. Spatial distribution of regionalized variables on reservoirs and groundwater resources based on geostatistical analysis using GIS: case of Rmel-Oulad Ogbane aquifers (Larache, NW Morocco). Arabian Journal of Geosciences 11(5):104 DOI 10.1007/s12517-018-3430-9.

Morales J, Rodríguez A, Alberto V, Machado C, Criado C. 2009. The impact of human activities on the natural environment of the canary islands (spain) during the pre-hispanic stage (3rd-2nd century bc to 15 th century ad): an overview. Environmental Archaeology 14(1): 27-36 DOI 10.1179/174963109X400655.

Nagy NM., Kónya J. 2007. Study of pH-dependent charges of soils by surface acid-base properties. Journal of Colloid \& Interface Science 305(1): 94-100 DOI 10.1016/j.jcis.2006.09.040.

Nasseh S, Moghaddas NH, Ghafoori M, Asghari O, Bazaz, JB. 2016. Spatial variability analysis of subsurface soil in the city of mashhad, northern east iran. International Journal of Mining and Geo-Engineering 50(2): 219-229 DOI 10.22059/ijmge.2016.59832.

Oliver MA, Webster R. 1986. Semi - variograms for modelling the spatial pattern of landform and soil properties. Earth Surface Processes \& Landforms 11(5): 491-504 DOI 10.1002/esp.3290110504.

Petrie SE, Jackson TL. 1984. Effects of fertilization on soil solution ph and manganese concentration1. Soil Science Society of America Journal 48: 315-318 DOI 10.2136/sssaj1984.03615995004800020018x.

Reijonen I, Metzler M, Hartikainen H. 2016. Impact of soil $\mathrm{pH}$ and organic matter on the chemical bioavailability of vanadium species: The underlying basis for risk assessment. Environmental Pollution 210: 371-379 DOI 10.1016/j.envpol.2015.12.046.

Riha SJ, Senesac G, Pallant E. 1986. Effects of forest vegetation on spatial variability of surface mineral soil ph, soluble aluminum and carbon. Water Air \& Soil Pollution 31(3-4): 929-940 DOI 10.1007/BF00284238.

Romano N. 1993. Use of an inverse method and geostatistics to estimate soil hydraulic conductivity for spatial variability analysis. Geoderma 60(1-4): 169-186 DOI 10.1016/0016-7061(93)90025-G.

Rosemary F, Vitharana UWA, Indraratne SP, Weerasooriya R, Mishra U. 2017. Exploring the spatial variability of soil properties in an alfisol soil catena. Catena 150: 53-61 DOI 10.1016/j.catena.2016.10.017.

Russenes AL, Korsaeth A, Bakken LR, Dörsch P. 2016. Spatial variation in soil ph controls off-season $\mathrm{N}_{2} \mathrm{O}$ emission in an agricultural soil. Soil Biology \& Biochemistry 99: 36-46 DOI 10.1016/j.catena.2016.10.017.

Salehi MH, Esfandiarpour I, Sarshogh M. 2011. The effect of aspect on soil spatial variability in central zagros, iran. Procedia Environmental Sciences 7: 293-298 DOI 


\subsection{6/j.proenv.2011.07.051.}

Schindelbeck RR, Es HMV, Abawi GS, Wolfe DW, Whitlow TL, Gugino BK, Idowu OJ, Moebius-Clune BN. 2008. Comprehensive assessment of soil quality for landscape and urban management. Landscape \& Urban Planning 88(2-4): 73-80 DOI 10.1016/j.catena.2016.10.017.

Sheoran V, Sheoran AS, Poonia P. 2010. Soil reclamation of abandoned mine land by revegetation: a review. International Journal of Soil Sediment \& Water 3: 1-21 http://works.bepress.com/as_sheoran/1/.

Shit PK, Bhunia GS, Maiti R. 2016. Spatial analysis of soil properties using GIS based geostatistics models. Modeling Earth Systems \& Environment 2(2):1-6 DOI 10.1007/s40808-016-0160-4.

Silvia P, Escalante AE, Noguez AM, Felipe GO, Celeste MP, Cram SS, Eguiarte LE, Souza. 2016. Spatial heterogeneity of physicochemical properties explains differences in microbial composition in arid soils from Cuatro Cienegas, Mexico. PeerJ 4(9): e2459 DOI 10.7717/peerj.24.

Stoyan H, De-Polli H, Böhm S, Robertson GP, Paul EA. 2000. Spatial heterogeneity of soil respiration and related properties at the plant scale. Plant \& Soil 222(1-2): 203-214 DOI 10.1023/A:1004757405147.

Trangmar BB, Yost RS, Uehara G. 1986. Application of geostatistics to spatial studies of soil properties. Advances in Agronomy 38(1): 45-94 DOI 10.1016/S0065-2113(08)60673-2.

Tsui CC, Chen ZS, Hsieh CF. 2004. Relationships between soil properties and slope position in a lowland rain forest of southern taiwan. Geoderma 123: 131-142 DOI 10.1016/j.geoderma.2004.01.031.

Turgut B, Öztaş T. 2012. Assessment of spatial distribution of some soil properties with geostatistics method. Ziraat Fakültesi Dergisi - Süleyman Demirel Üniversitesi 7(2): 10-22 https://www.researchgate.net/publication/246548713.

Vieira SR, Filho OG, Chiba MK. Cantarella H. 2009. Spatial variability of soil chemical properties after coffee tree removal. Revista Brasileira De Ciência Do Solo 33(5): 15071514 DOI 10.1590/S0100-06832009000500041.

Wang HJ, Shi XZ, Yu DS, Weindorf DC, Huang B, Sun WX, Ritsema CJ, Milne E. 2009. Factors determining soil nutrient distribution in a small-scaled watershed in the purple soil region of Sichuan Province, China. Soil \& Tillage Research 105(2):300-306 DOI 10.1016/j.still.2008.08.010.

Wang Y, Shao M, Zhu Y, Liu Z. 2011. Impacts of land use and plant characteristics on dried soil layers in different climatic regions on the loess plateau of china. Agricultural \& Forest Meteorology 151: 437-448 DOI 10.1016/j.agrformet.2010.11.016.

Wang Y, Zhang X, Huang C. 2009. Spatial variability of soil total nitrogen and soil total phosphorus under different land uses in a small watershed on the loess plateau, china. Geoderma 150(1): 141-149 DOI 10.1016/j.geoderma.2009.01.021.

Wilding LP. 1985. Spatial variability: its documentation, accommodation and implication to soil survey. Spatial Variations 166-194. 
Yan LB, He RX, Kašanin-Grubin M, Luo GX, Peng H, Qiu JX. 2017. The dynamic change of vegetation cover and associated driving forces in nanxiong basin, china. Sustainability 9(3): 443-457 DOI 10.3390/su903044.

Yang J, Chen H, Nie Y, Zhang W, Wang K. 2016. Spatial variability of shallow soil moisture and its stable isotope values on a karst hillslope. Geoderma 264: 61-70 DOI 10.1016/j.geoderma.2015.10.003.

Yüksek T, Göl C, Yüksek F, Yüksel EE. 2009. The effects of land-use changes on soil properties: the conversion of alder coppice to tea plantations in the humid northern blacksea region. African Journal of Agricultural Research 4(7): 665-674 http://www.academicjournals.org/AJAR.

Zaremehrjardi M, Taghizadehmehrjardi R, Akbarzadeh A. 2010. Evaluation of geostatistical techniques for mapping spatial distribution of soil $\mathrm{pH}$, salinity and plant cover affected by environmental factors in southern iran. Notulae Scientia Biologicae 2(4): 92103 http://www.notulaebiologicae.ro.

Zhang C, Li W. 2010. Regional-scale modelling of the spatial distribution of surface and subsurface textural classes in alluvial soils using markov chain geostatistics. Soil Use \& Management 24(3): 263-272 DOI 10.1111/j.1475-2743.2008.00165.x.

Zhang JH, Li Y. 2002. Spatial variability of soil moisture on the hillslopes, southwestern china. Archives of Agronomy \& Soil Science 48(4): 357-362 DOI 10.1080/036503402141.

Zhang Q, Yang ZP, Li Y, Chen DL, Zhang JJ, Chen MC. 2010. Spatial variability of soil nutrients and gis-based nutrient management in yongji county, china. International Journal of Geographical Information Science 24(7): 965-981 DOI 10.1080/13658810903257954.

Zhao BH, Li ZB, Li P, Xu G, Gao HD, Cheng YT, Chang EH, Yuan SL, Zhang Y, Feng ZH. 2017. Spatial distribution of soil organic carbon and its influencing factors under the condition of ecological construction in a hilly-gully watershed of the loess plateau, china. Geoderma 296: 10-17 DOI 10.1016/j.geoderma.2017.02.010.

Zhao FY, Wu FZ, Liu D. 2000. Studies on the physical and chemical properties of the protected vegetable soils. Soil and Fertilizer 2: 11-23.

Zhao J, Dong Y, Xie X, Li X, Zhang XX, Shen X. 2011. Effect of annual variation in soil $\mathrm{pH}$ on available soil nutrients in pear orchards. Acta Ecologica Sinica 31(4): 212-216 DOI 10.1016/j.chnaes.2011.04.001.

Zucco G, Brocca L, Moramarco T, Morbidelli R. 2014. Influence of land use on soil moisture spatial-temporal variability and monitoring. Journal of Hydrology 516(6): 193-199 DOI 10.1016/j.jhydro1.2014.01.043. 


\section{Figure 1}

Location map of the study area

Adapted from "The Dynamic Change of Vegetation Cover and Associated Driving Forces in Nanxiong Basin, China" by Luobin Yan, et al, 2017, Sustainability, 9(3), 443. Reprinted with permission: this is an open access article distributed under the Creative Commons Attribution License which permits unrestricted use, distribution, and reproduction in any medium, provided the original work is properly cited (CC BY 4.0). 


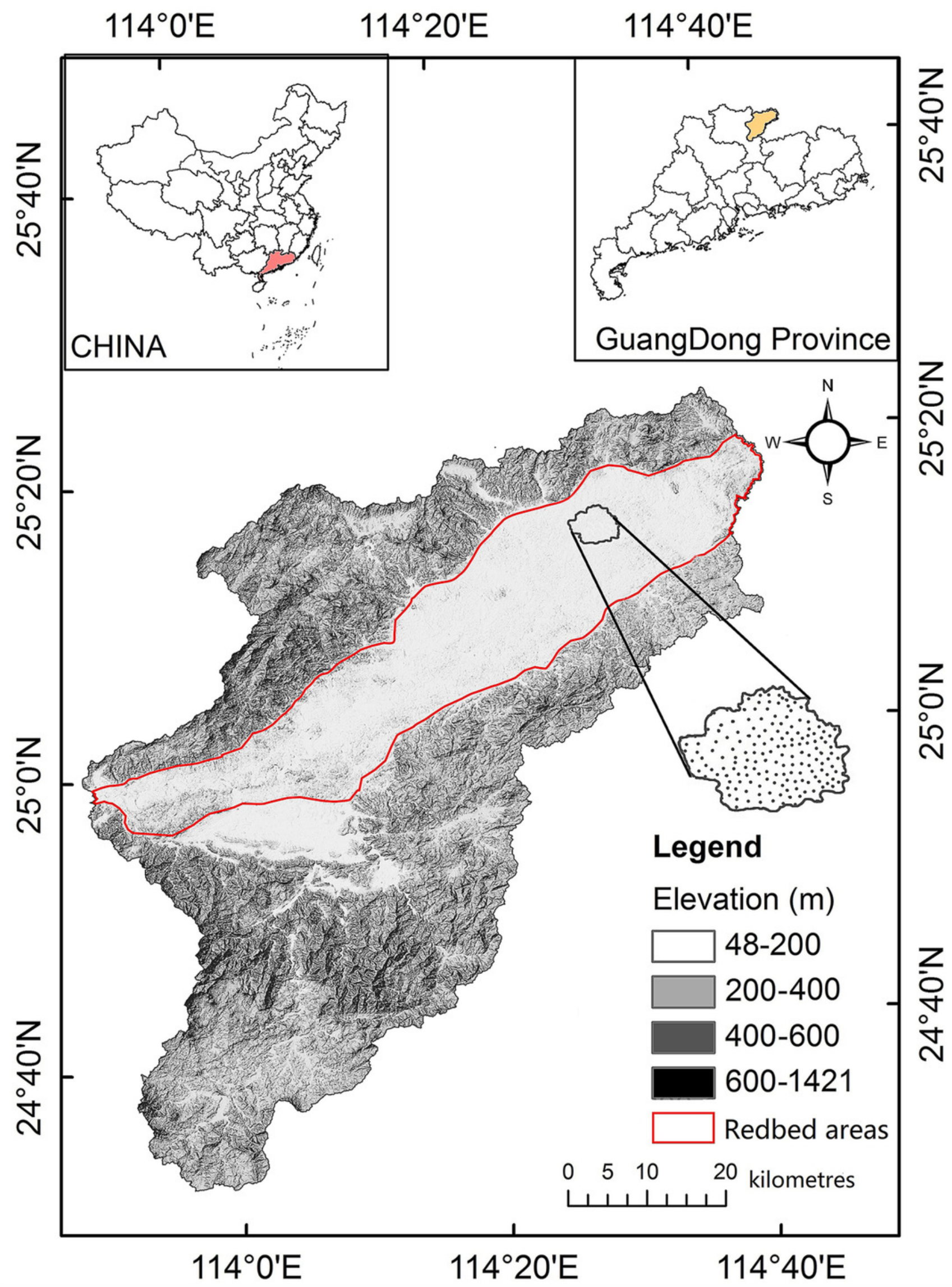

Adapted from "The Dynamic Change of Vegetation Cover and Associated Driving Forces in Nanxiong Basin, China"by Luobin Yan, et al, 2017,

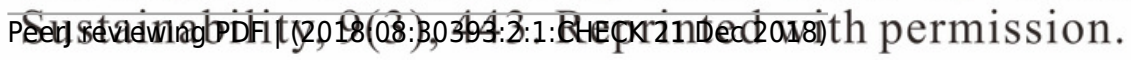


Figure 2

Location map of sampling point.

Photo by Ping Yan.

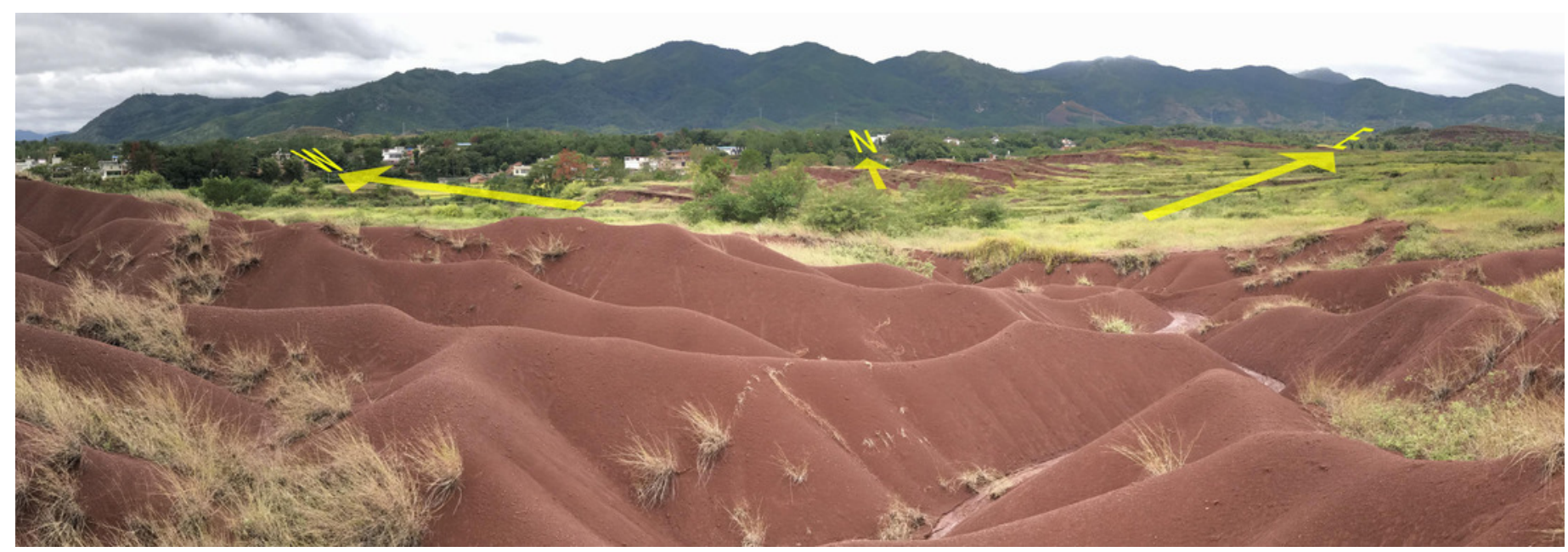


Figure 3

Land-use map of Nanxiong Basin in 2010.

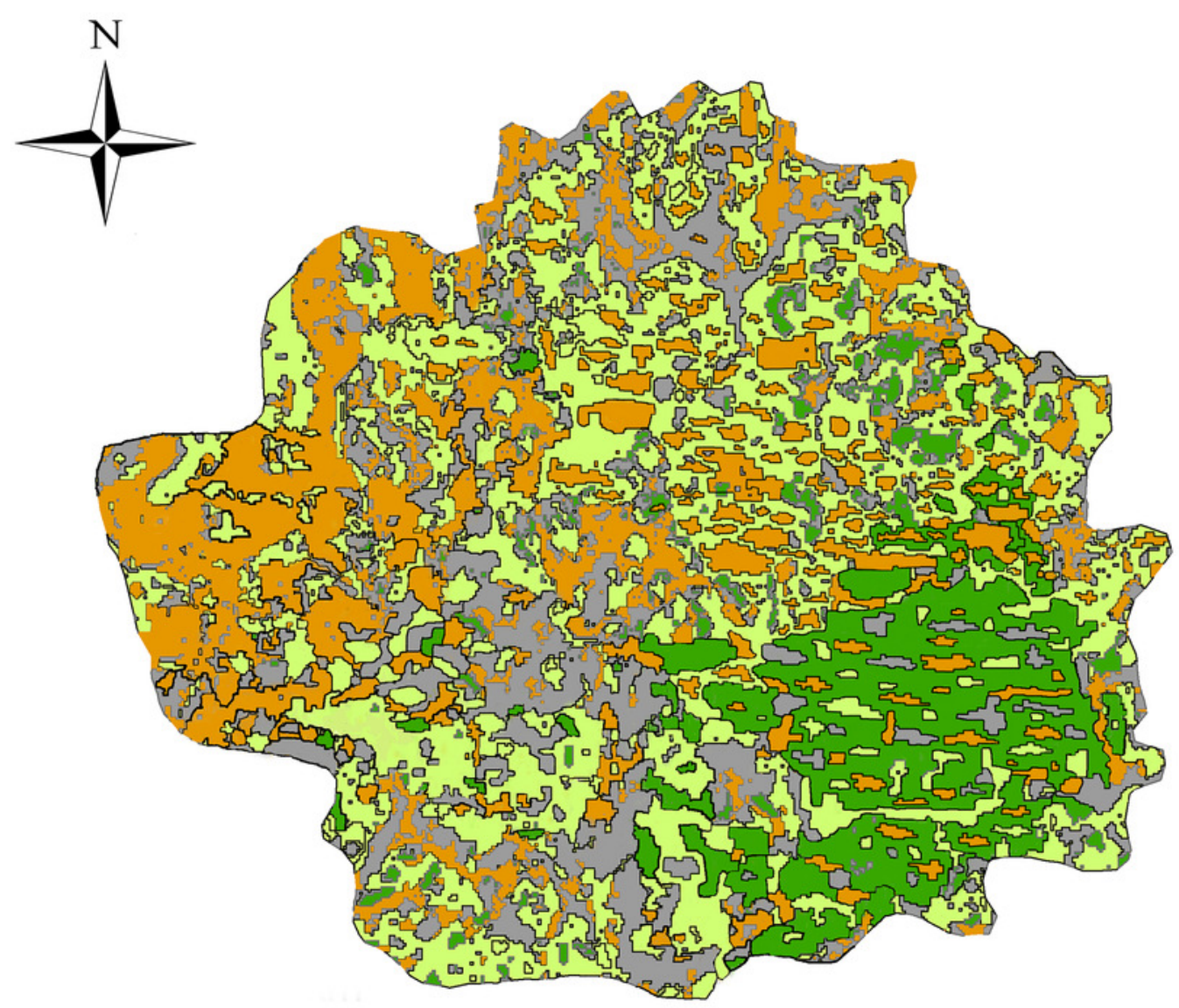

Legend

Land use pattern

\begin{tabular}{l} 
Bareland \\
\hline Grassland
\end{tabular}

\begin{tabular}{llll}
0 & 0.5 & 1 & 2 \\
\hline
\end{tabular}

Farmland

Woodland 
Figure 4

Trend of the cumulative frequency of soil pH.

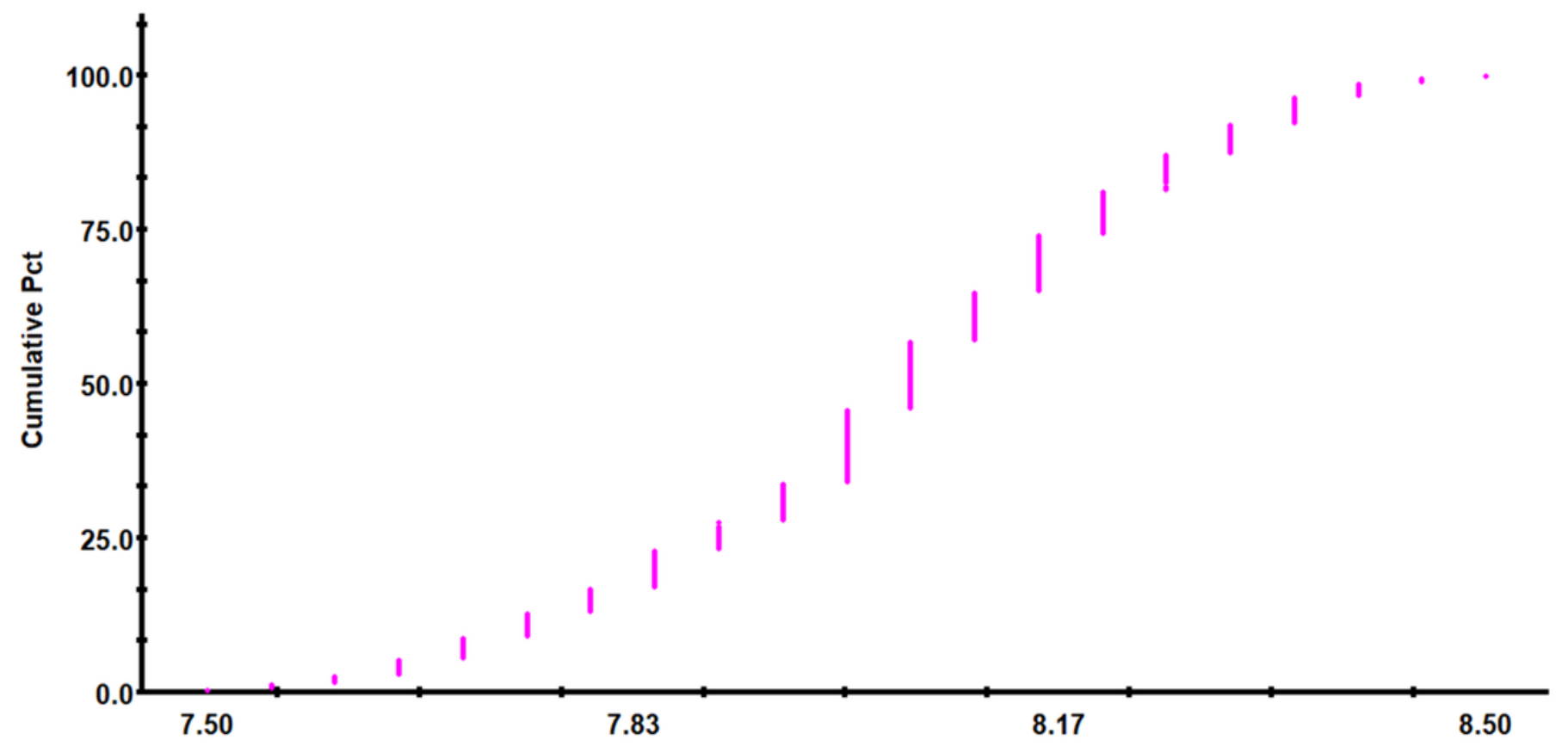


Figure 5

Isotropic semivariance of soil pH.

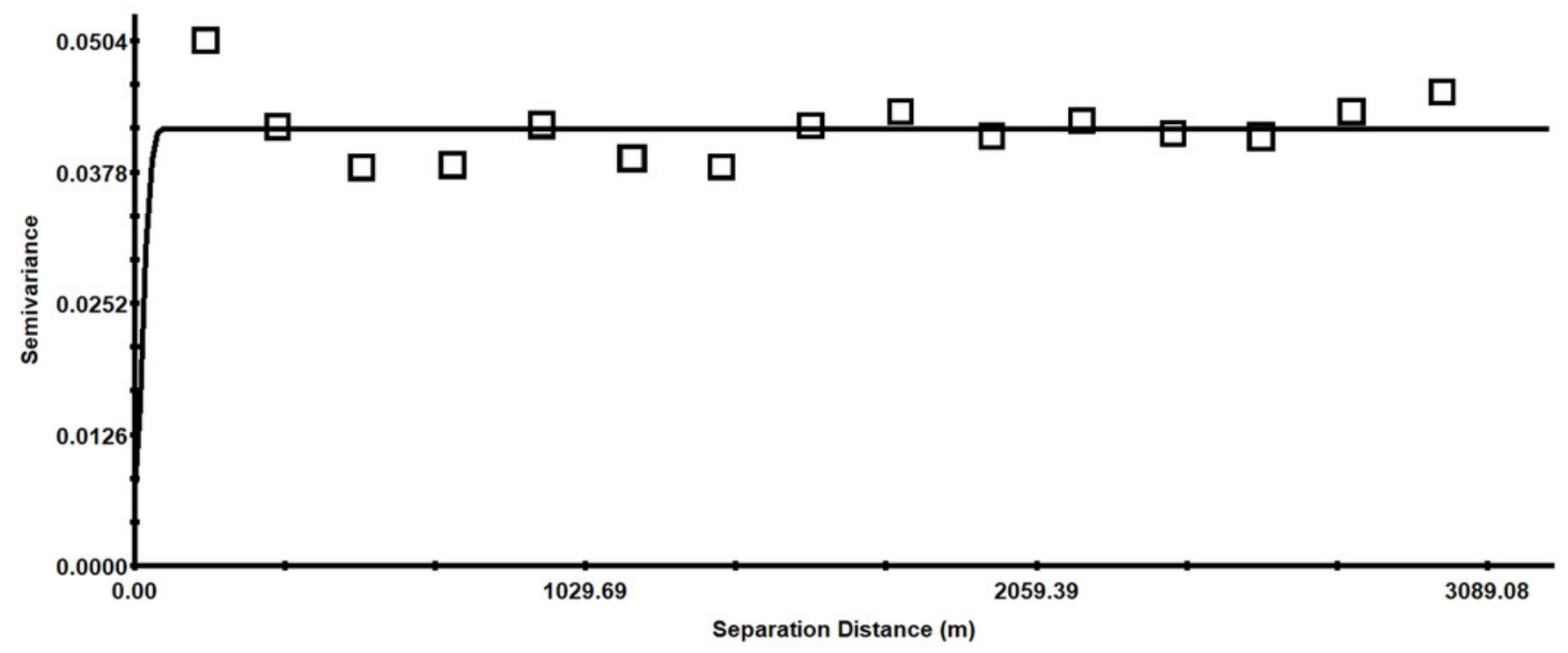




\section{Figure 6}

Anisotropic semi-variance of soil pH.

The semivariogram of the spatial variation in soil $\mathrm{pH}$ was drawn in directions of $\mathrm{E}-\mathrm{W}\left(0^{\circ}\right)$ in Figure $6(A)$; the semivariogram of the spatial variation in soil pH was drawn in directions of $\mathrm{NE}-\mathrm{SW}\left(45^{\circ}\right)$ in Figure $6(\mathrm{~B})$; the semivariogram of the spatial variation in soil $\mathrm{pH}$ was drawn in directions of S-N $\left(90^{\circ}\right)$ in Figure $6(\mathrm{C})$; the semivariogram of the spatial variation in soil $\mathrm{pH}$ was drawn in directions of SE-NW $\left(135^{\circ}\right)$ in Figure 6 (D).
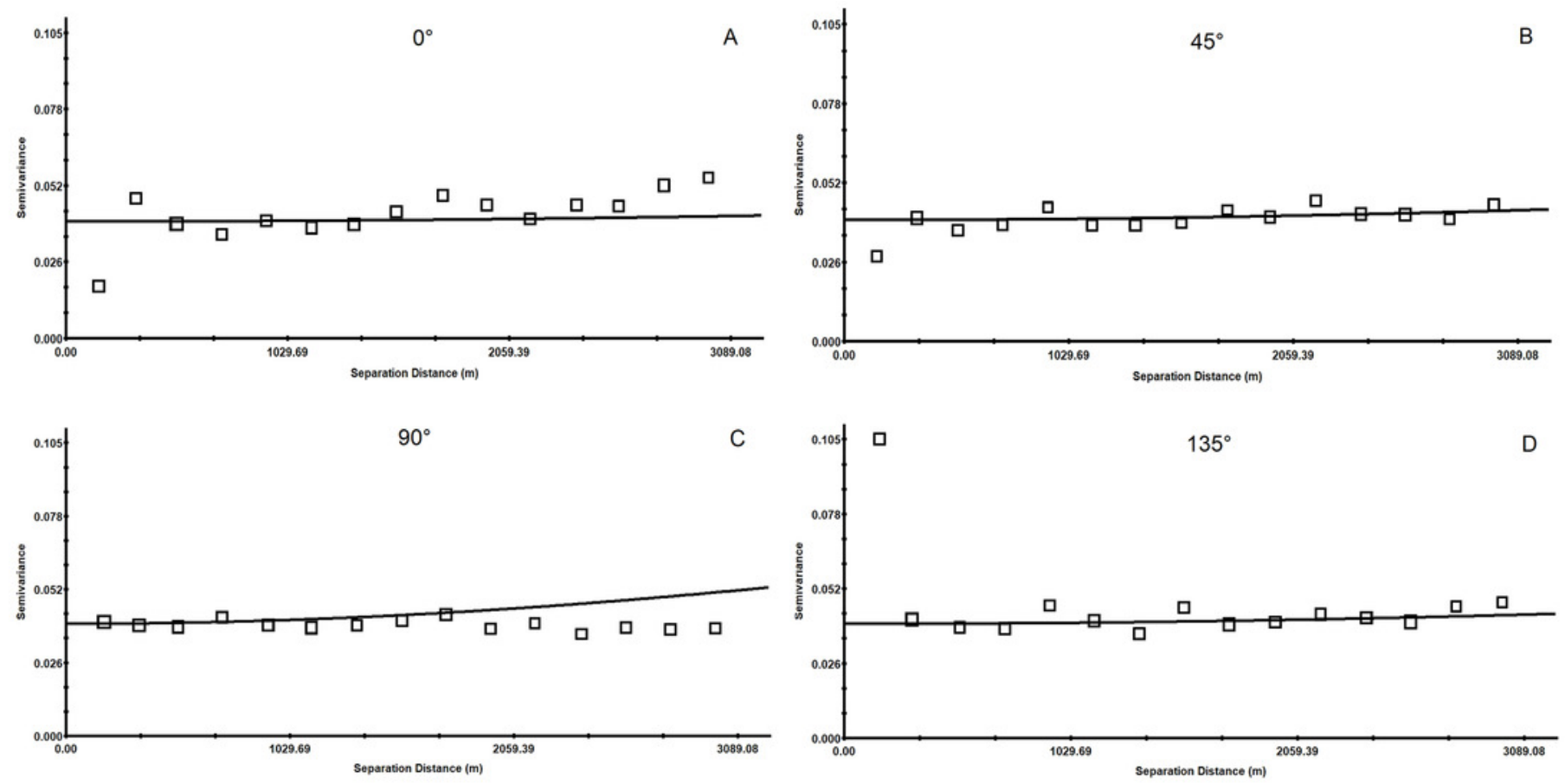
Figure 7

Analysis of soil pH trend.

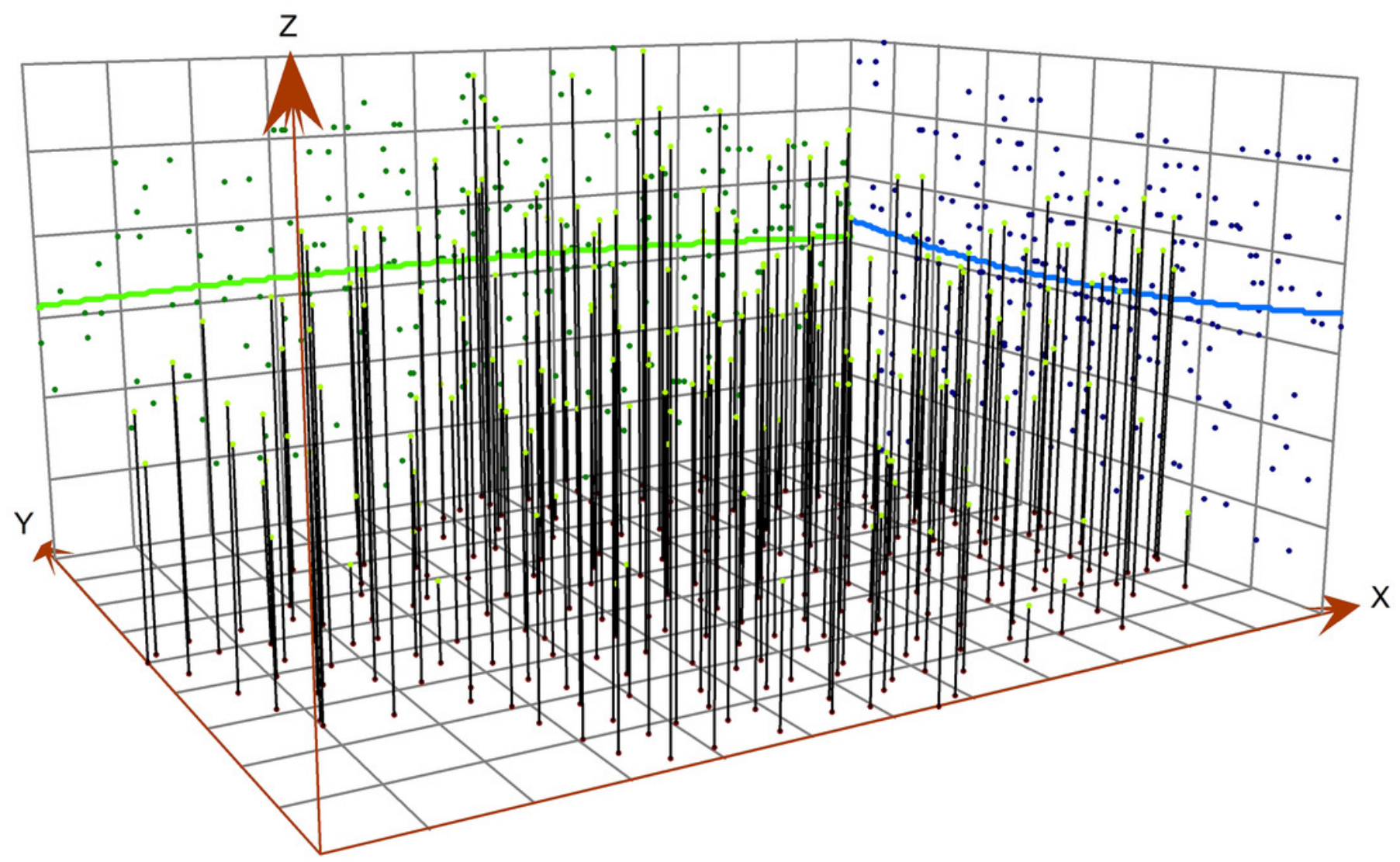


Figure 8

Kriging interpolation map.

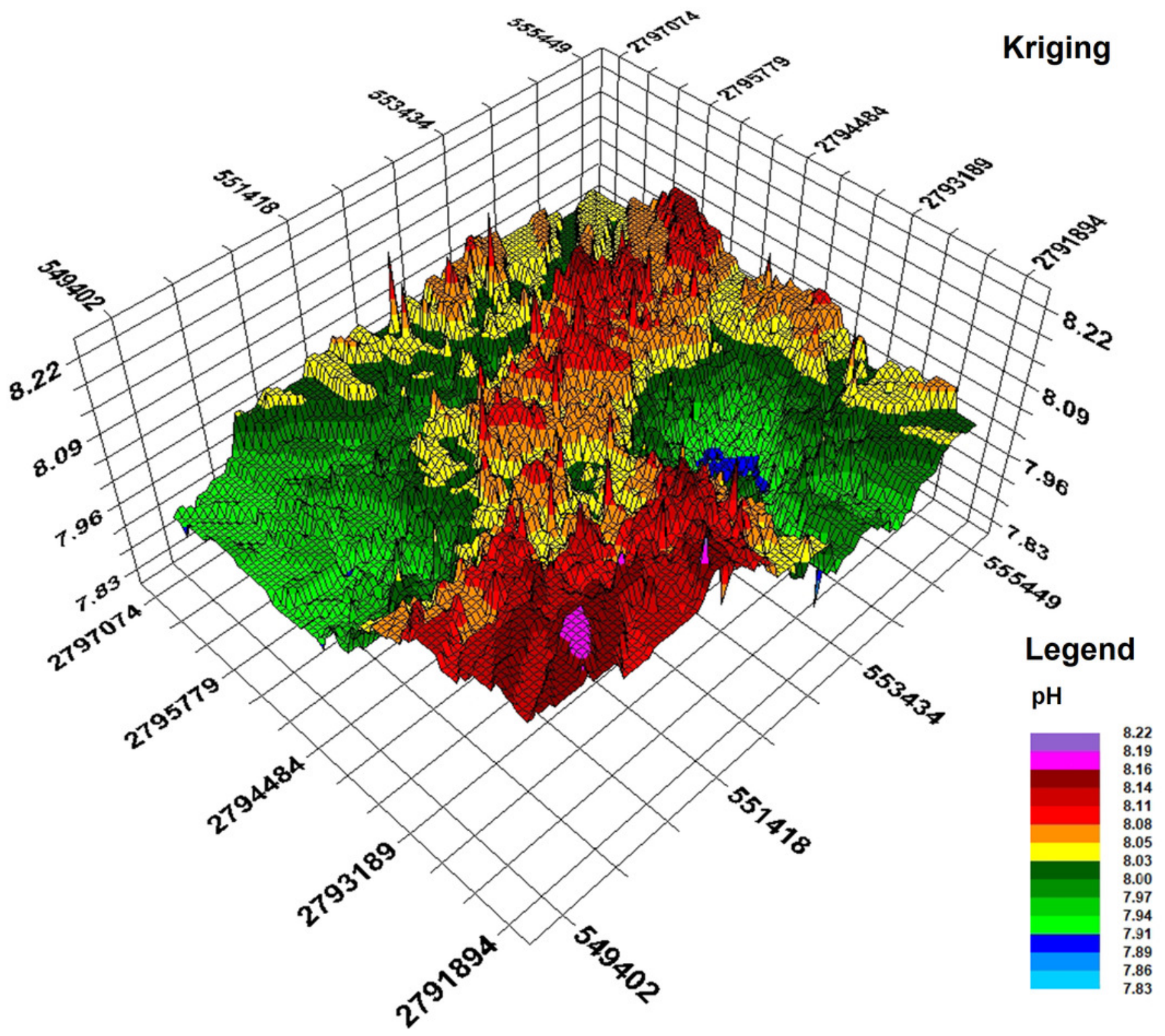


Figure 9

Inverse distance weighting interpolation map.

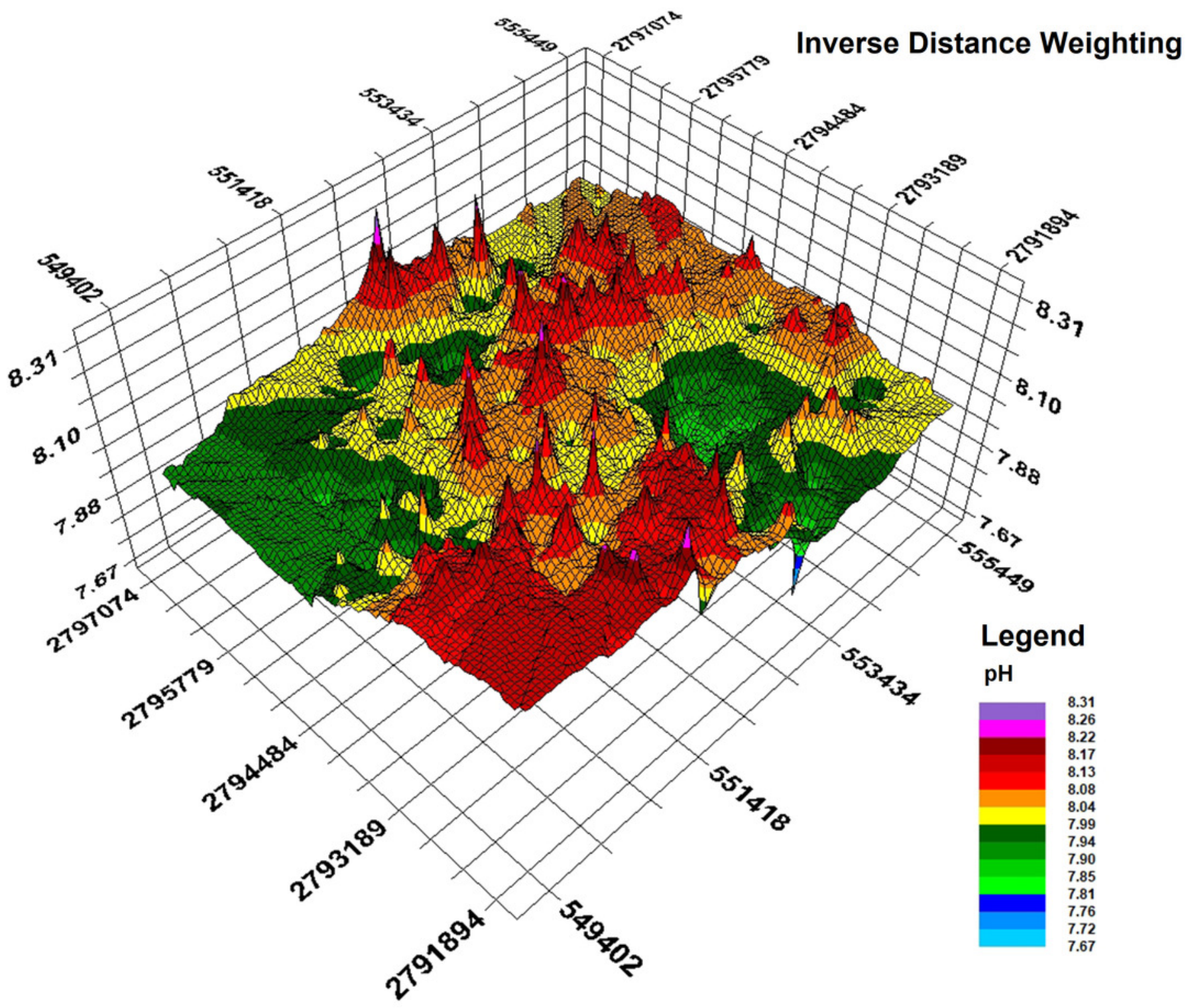


Figure 10

Slope distribution map.

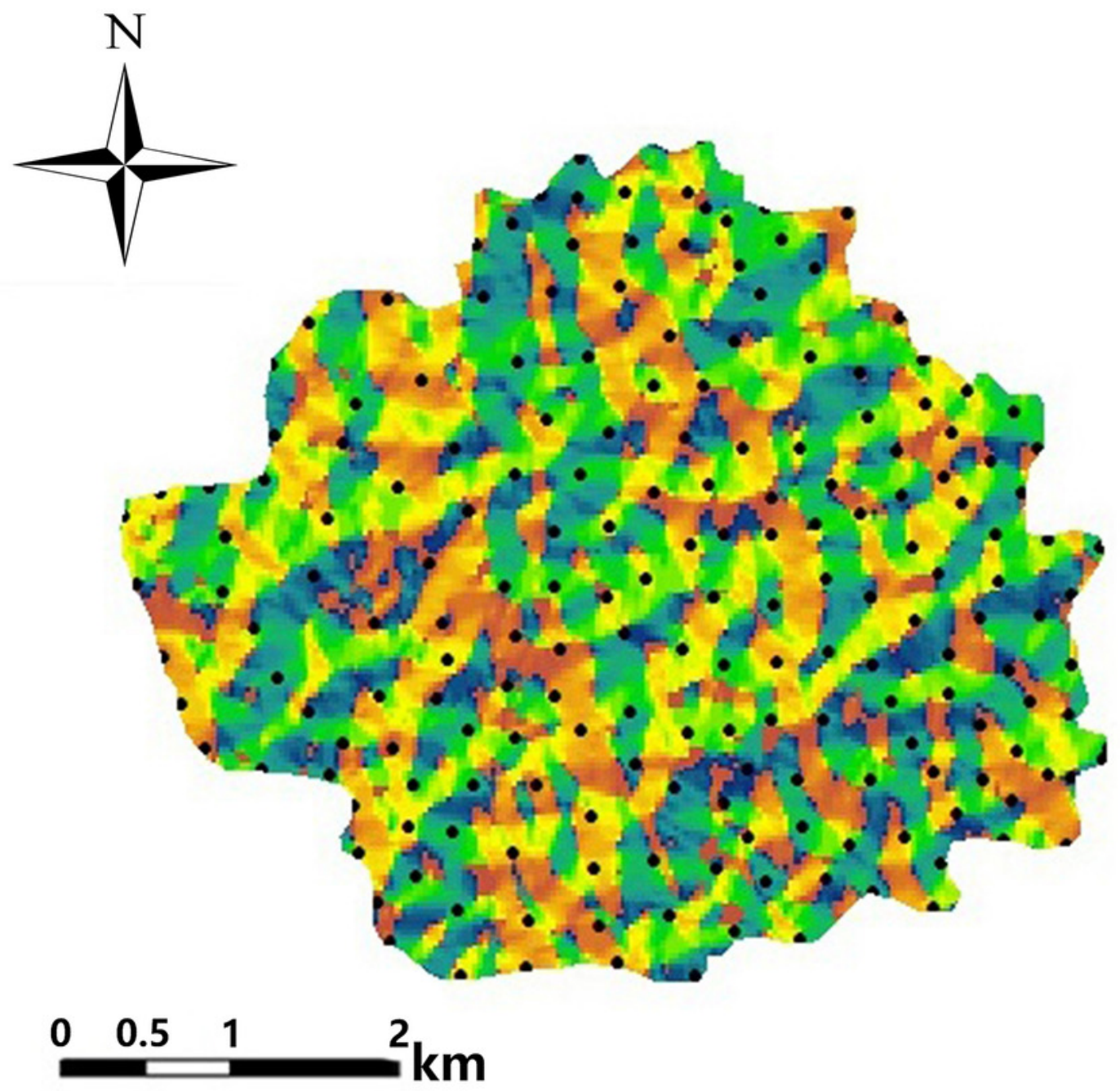

Legend - Sampling point Aspect High 360 Low 0 
Figure 11

Spatial distribution map of soil pH.

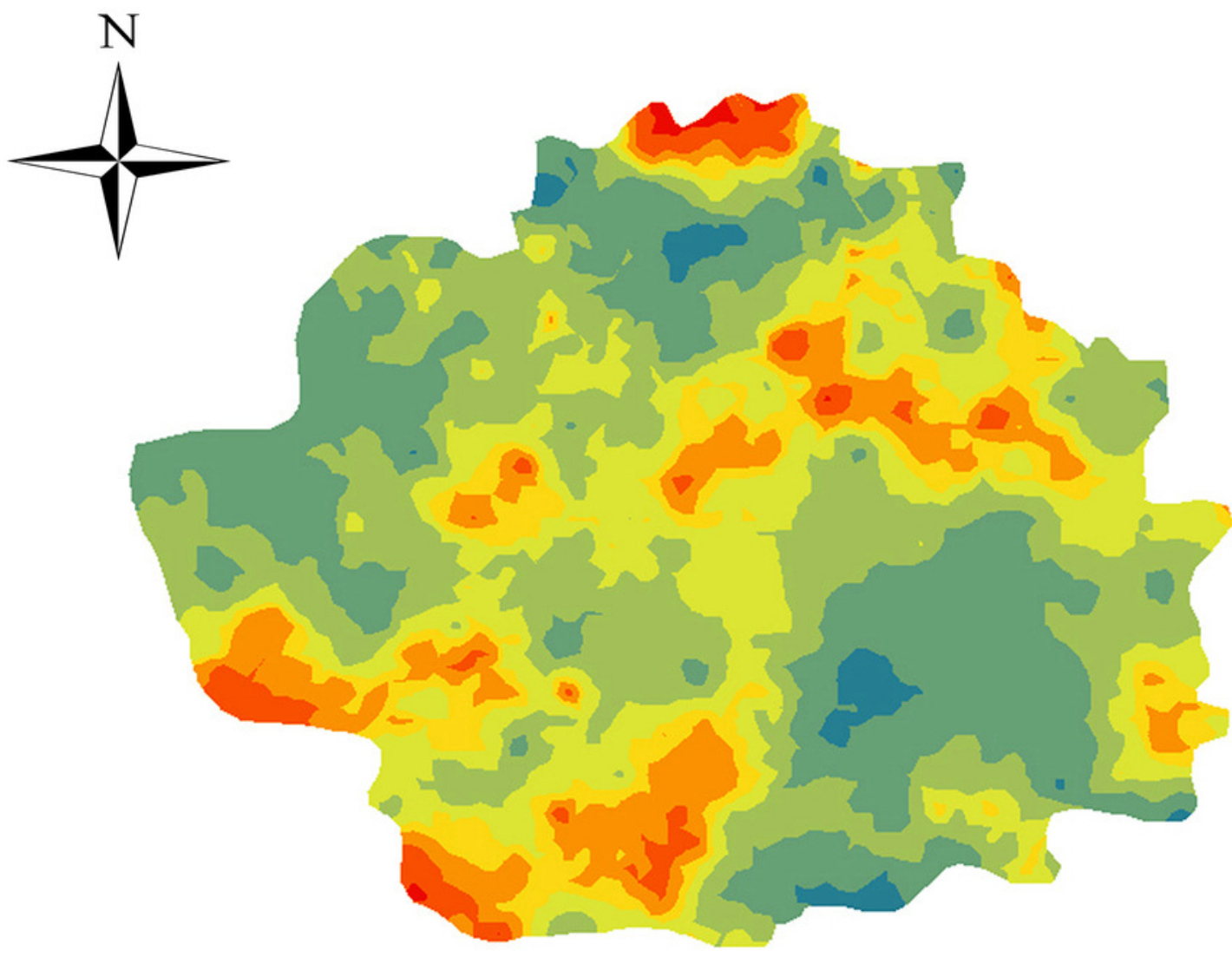

\section{Legend} $\mathrm{pH}$ value

\begin{tabular}{llll}
0 & 0.5 & 1 & 2 \\
\hline
\end{tabular}

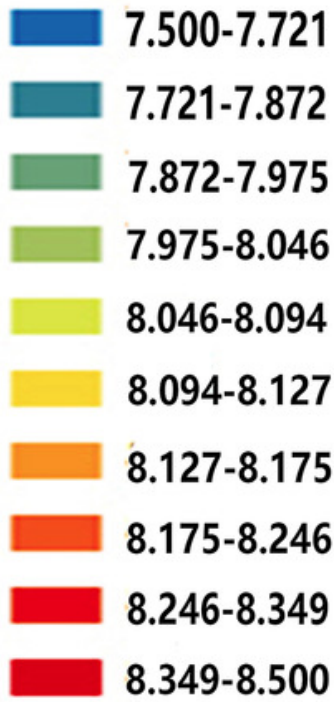


Figure 12

Different land use patterns of soil $\mathrm{pH}$.

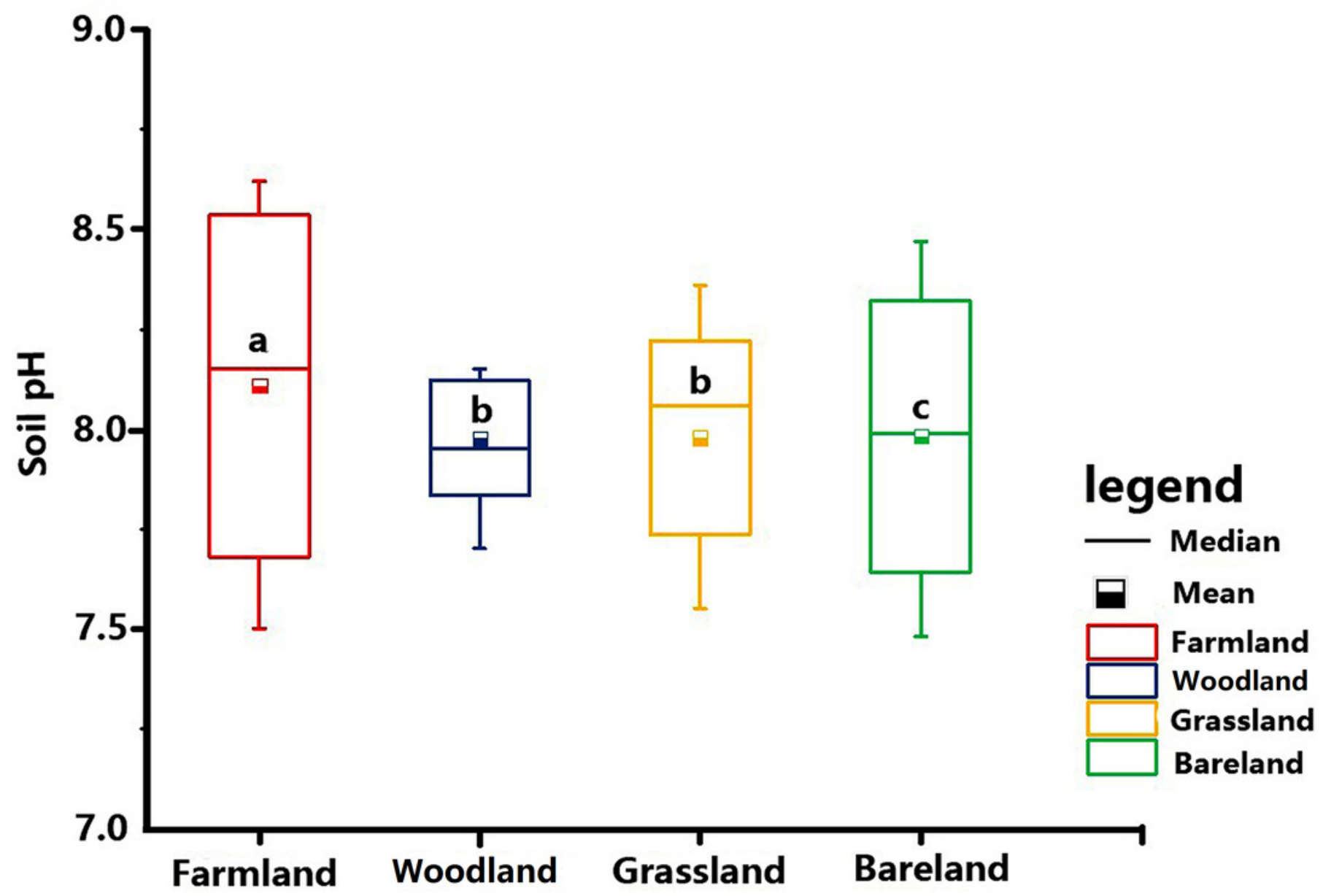


Table $\mathbf{1}$ (on next page)

Statistical characteristic values of soil pH. 
1 Table 1 Statistical characteristic values of soil pH.

\begin{tabular}{|c|c|c|c|c|c|c|c|c|c|}
\hline $\begin{array}{l}\text { Soil } \\
\text { properties }\end{array}$ & $\begin{array}{l}\text { Sample } \\
\text { size }\end{array}$ & Range & Median & Mean & $\begin{array}{l}\text { Standard } \\
\text { deviation }\end{array}$ & Skewness & Kurtosis & $\begin{array}{l}\text { Coefficient } \\
\text { of variation } \\
(\%)\end{array}$ & $\begin{array}{l}\text { K-S } \\
\text { test }\end{array}$ \\
\hline $\mathrm{pH}$ & 225 & $7.50-8.50$ & 8.05 & 8.04 & 1.38 & -0.25 & -0.42 & 17.18 & 0.10 \\
\hline
\end{tabular}

2 
Table 2 (on next page)

Isotropic semivariogram theory model and related parameters of soil pH. 
1 Table 2 Isotropic semivariogram theory model and related parameters of soil $\mathbf{p H}$.

\begin{tabular}{lcccccc}
\hline Soil & Theoretical model & $\begin{array}{c}\text { Nugget } \\
\text { property }\end{array}$ & Sill & Nugget/Sill & Range & $\begin{array}{c}\text { Determining } \\
\text { coefficient }\left(\mathrm{R}^{2}\right)\end{array}$ \\
& & & $\left(\mathrm{C}_{0}\right)$ & $\left(\mathrm{C}_{0}+\mathrm{C}\right)$ & $(\mathrm{m})$ & \\
\hline Soil pH & Spherical model & 0.12 & 0.18 & 66.67 & 161 & 0.812 \\
\hline
\end{tabular}

2 


\section{Table 3 (on next page)}

Anisotropic semivariogram theory model and related parameters of soil $\mathrm{pH}$. 
1 Table 3 Anisotropic semivariogram theory model and related parameters of soil $\mathbf{p H}$.

\begin{tabular}{|c|c|c|c|c|c|c|c|}
\hline $\begin{array}{l}\text { Soil } \\
\text { property }\end{array}$ & Direction & $\begin{array}{l}\text { Theoretical } \\
\text { model }\end{array}$ & $\begin{array}{l}\text { Nugget } \\
\left(\mathrm{C}_{0}\right)\end{array}$ & $\begin{array}{l}\text { Sill } \\
\left(\mathrm{C}_{0}+\mathrm{C}\right. \\
)\end{array}$ & $\begin{array}{l}\text { Nugget/Sill } \\
(\%)\end{array}$ & Range & $\begin{array}{l}\text { Determining } \\
\text { coefficient }\left(\mathrm{R}^{2}\right. \\
)\end{array}$ \\
\hline \multirow{4}{*}{ Soil pH } & $0^{\circ}$ & Spherical model & 0.27 & 0.39 & 69.23 & 161 & 0.539 \\
\hline & $45^{\circ}$ & Spherical model & 0.32 & 0.47 & 68.09 & 172 & 0.586 \\
\hline & $90^{\circ}$ & Spherical model & 0.29 & 0.48 & 60.42 & 169 & 0.612 \\
\hline & $135^{\circ}$ & Spherical model & 0.35 & 0.51 & 68.62 & 182 & 0.509 \\
\hline
\end{tabular}

2 


\section{Table 4 (on next page)}

The influence of slope and slope position on soil pH.

The difference between the letters in the same column is significant $(P<0.05)$, and the letters in brackets indicate significant difference $(P<0.05)$. 
1 Table 4 The influence of slope and slope position on soil pH. The difference between the letters in the same column is 2 significant $(P<0.05)$, and the letters in brackets indicate significant difference $(P<0.05)$.

\begin{tabular}{llll}
\hline \multirow{2}{*}{ Slope } & \multicolumn{3}{c}{$0-20 \mathrm{~cm}$ Soil layer } \\
\cline { 2 - 4 } & Upper slope & Middle slope & Down slope \\
\hline $10^{\circ}$ & $8.41 \pm 0.11 \mathrm{a}(\mathrm{a})$ & $8.39 \pm 0.02 \mathrm{a}(\mathrm{a})$ & $8.01 \pm 0.09 \mathrm{~b}(\mathrm{a})$ \\
$15^{\circ}$ & $8.32 \pm 0.14 \mathrm{a}(\mathrm{a})$ & $8.29 \pm 0.01 \mathrm{a}(\mathrm{a})$ & $8.15 \pm 0.01 \mathrm{~b}(\mathrm{a})$ \\
& & & $8.26 \pm 0.06 \mathrm{ab}(\mathrm{a})$ \\
$20^{\circ}$ & $8.09 \pm 0.09 \mathrm{~b}(\mathrm{~b})$ & & $8.35 \pm 0.12 \mathrm{a}(\mathrm{a})$ \\
\hline
\end{tabular}

3 


\section{Table 5 (on next page)}

Semivariogram models and model parameters for soil properties in four land uses. 
1 Table 5 Semivariogram models and model parameters for soil properties in four land uses.

\begin{tabular}{|c|c|c|c|c|c|c|c|}
\hline $\begin{array}{l}\text { Land use } \\
\text { patterns }\end{array}$ & $\begin{array}{l}\text { Theoretical } \\
\text { model }\end{array}$ & $\begin{array}{l}\text { Coefficient of } \\
\text { variation (\%) }\end{array}$ & $\begin{array}{l}\text { Nugget } \\
\left(\mathrm{C}_{0}\right)\end{array}$ & $\begin{array}{l}\text { Sill } \\
\left(\mathrm{C}_{0}+\mathrm{C}\right)\end{array}$ & $\begin{array}{l}\text { Nugget/Sill } \\
(\%)\end{array}$ & $\begin{array}{l}\text { Range } \\
\text { (m) }\end{array}$ & $\begin{array}{l}\text { Determining } \\
\text { coefficient }\left(\mathrm{R}^{2}\right)\end{array}$ \\
\hline Farmland & Spherical model & 17.25 & 0.22 & 0.37 & 59.15 & 195 & 0.62 \\
\hline Forestland & Spherical model & 17.09 & 0.31 & 0.48 & 63.49 & 180 & 0.58 \\
\hline Grassland & Spherical model & 16.95 & 0.21 & 0.34 & 62.12 & 175 & 0.56 \\
\hline Bareland & Spherical model & 14.21 & 0.19 & 0.29 & 65.59 & 181 & 0.59 \\
\hline
\end{tabular}

2 